\title{
Peningkatan Kualitas Teknologi Produksi Dan Tata Kelola Usaha Pada Usaha Apem Selong dan Putu Dahlok Jember
}

\author{
Improvement of Production Technology and Business Governance in Apem Selong and Putu \\ Dahlok Jember Business
}

\author{
Sumadi ${ }^{1}$, Oryza Ardhiarisca ${ }^{1}$, Rahma Rina Wijayanti ${ }^{1}$, Rediyanto Putra ${ }^{2 *}$ \\ 1 Jurusan Manajemen Agribisnis, Politeknik Negeri Jember \\ 2 Fakultas Ekonomi, Universitas Negeri Surabaya \\ *rediputra@gmail.com
}

\begin{abstract}
ABSTRAK
Program pengabdian ini akan dilakukan pada usaha Apem Selong \& Putu Dahlok Jember. Usaha ini terletak di Jl. Fatahilah, Tembaan, Kepatihan, Kec. Kaliwates, Kabupaten Jember Provinsi Jawa Timur. Kegiatan PKM ini dilakukan dengan tujuan untuk meningkatkan perkembangan dari usaha Apem Selong dan putu Dahlok Jember dari segi tempat usaha, peralatan, pemasaran, kebersihan dan produk. Dengan demikian, usaha Apem Selong dan Putu Dahlok ini bisa lebih optimal dalam memperoleh keuntungan. Perbaikan peralatan dilakukan dengan menambah atau memperbarui peralatan yang sebelumnya dimiliki oleh mitra. Dengan demikian, perbaikan peralatan perlu dilakukan agar usaha mitra lebih efisien dan efektivitas dalam menghasilkan produk, sehingga keuntungan yang diperoleh menjadi lebih optimal. Perbaikan peralatan ini akan sepenuhnya melibatkan mitra dalam hal penentuan spesifikasi alat yang akan digunakan. Hal ini dikarenakan mitra merupakan pihak yang mengetahui sepesifikasi seperti apa yang harus ada dalam alat yang akan digunakan. Adapun alat yang dibutuhkan oleh usaha apem selong dan putu Dahlok adalah kompor dengan ukuran dan tekanan api yang lebih besar dan panci putu dengan ukuran yang lebih besar dan berbahan stainless steel. Berdasarkan perhitungan biaya produksi yang telah dilakukan maka diketahui bahwa usaha Apem Selong dan Putu Dahlok mendapatkan keuntungan sebesar Rp189.100,- per hari jika seluruh produknya terjual.
\end{abstract}

Kata kunci - Biaya produksi, Keuntungan, Teknologi

\begin{abstract}
This service program will be conducted at the efforts of Apem Selong \&Putu Dahlok Jember. This business is located on Jl. Fatahilah, Tembaan, Kepatihan, Kec. Kaliwates, Jember Regency, East Java Province. PkM activities are carried out with the aim to improve the development of the business Apem Selong and Putu Dahlok Jember in terms of business premises, equipment, marketing, cleanliness and products. Thus, the efforts of Apem Selong and Putu Dahlok can be more optimal in gaining profit. Equipment repair is done by adding or updating equipment previously owned by partners. Thus, equipment repair needs to be done in order for partner efforts to be more efficient and effective in producing products, so that the profit obtained becomes more optimal. Repair of this equipment will fully involve the partner in terms of determining the specifications of the tool to be used. This is because the partner is a party that knows what kind of disme should be in the tool to be used. The tools needed by the business apem selong and putu dahlok is a stove with a larger size and fire pressure and a putu pot with a larger size and made of stainless steel. Based on the calculation of production costs that have been done, it is known that the efforts of Apem Selong and Putu Dahlok get a profit of Rp189.100,- per day if all products are sold.
\end{abstract}

Keywords - Production Costs, Advantages, Production Technology 


\section{Pendahuluan}

Wabah covid-19 saat ini sudah menyebar di Indonesia. Hingga saat ini, tanggal 15 April 2020 telah terkonfirmasi warga Indonesia yang positif corona ada 5.136 kasus. Dari kasus tersebut, 4.221 orang dirawat di rumah sakit dan 469 orang meninggal dunia [1]. Respons pemerintah adalah dengan mengeluarkan beberapa aturan, himbauan, dan kebijakan. Salah satu himbauan yang dikeluarkan pemerintah adalah sosial dan physical distancing. Warga harus menjaga jarak antar satu dengan yang lainnya. Bahkan pemerintah mengeluarkan edaran tentang diadakannya work from home, school from home, dan pray from home. Sehingga masyarakat diharapkan stay at home. Hal ini bertujuan untuk memutuskan tali penyebaran virus tersebut. Selain itu, di Kabupaten Jember, Bupati Faida, telah mengeluarkan aturan pembatasan jam operasional pasar dan juga penutupan jalan di sekitar alun-alun kota, pusat keramaian, pada hari Sabtu dan Minggu sejak 28 Maret 2020 [2]. Hal ini berdampak pada berbagai sektor, salah satunya, pada UMKM. UMKM mengalami penurunan penjualan dan produksi [3].

Salah satu, UMKM di Jember yang terkena dampaknya adalah UMKM Apem Selong dan Putu Dahlok berdiri pada tahun 1958. UMKM Apem Selong dan Putu Dahlok terkena dampak dari adanya social dan physical distancing yang ada di Kabupaten Jember karena adanya pembatasan akses di alun-alun Kab Jember yang dekat dengan lokasi usaha. Awalnya UMKM ini dikelola oleh Bapak Parno dan istri. Sepeninggal keduanya, kini bisnis ini dijalankan oleh putri mereka, Ibu Prihatiningsih dan dibantu oleh Bapak Gatot dan Ibu Warda. Usaha ini mulai mempersiapkan dagangannya pukul 16.00 dan buka mulai pukul 18.00 sampai 23.00. Usaha ini buka pada hari Senin hingga Sabtu, sedangkan tutup pada hari minggu. Namun, kini dengan menyebarnya wabah Covid-19, UMKM ini mengalami penurunan penjualan karena tidak dapat berjualan pada hari Sabtu dan minggu dan sepi pembeli akibat social distancing. Produk yang dijual adalah apem selong dan putu. Apem selong dan putu merupakan kue tradisional yang perlu dipertahankan dan dilestarikan keberadaannya. Kedua jenis produk ini menggunakan bahan tepung beras dan kelapa, hanya proses pembuatan yang berbeda. Pembuatan apem selong menggunakan cetakan yang dipanggang dengan adonan cair. Sedangkan pembuatan putu ayu menggunakan cetakan bambu yang dikukus dengan adonan yang padat.

Peralatan yang digunakan oleh usaha ini adalah kompor, cetakan apem selong, cetakan putu, kukusan putu, sutil dan wadah. Kompor yang digunakan adalah kompor biasa satu tungku. Sedangkan untuk, penggunaan kompor ini masih perlu memberikan dampak maksimum. Kompor yang seharusnya digunakan adalah kompor joss high pressure dengan dua tungku sehingga dapat memberikan tekanan maksimal dalam proses pembuatan putu dan apem selong. Peralatan kedua yang digunakan adalah cetakan apem. Usaha ini memiliki dua buah cetakan apem. Cetakan apem yang digunakan adalah cetakan apem isi empat, seperti pada Gambar 1.

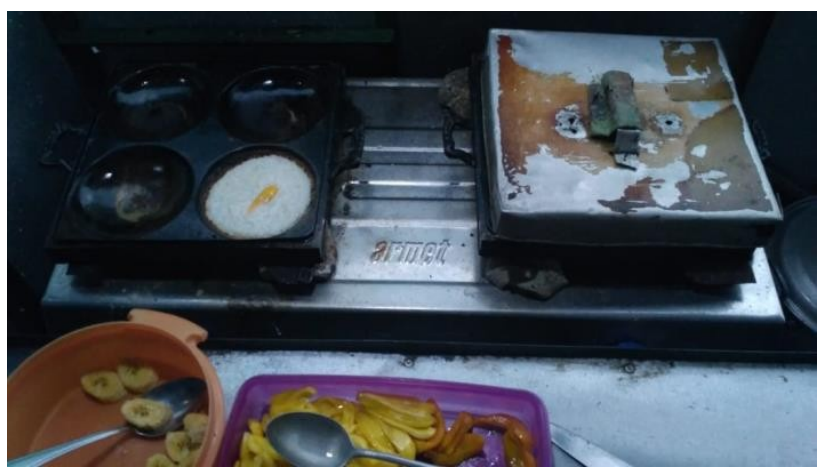

Gambar 1. Cetakan Apem

Peralatan ketiga adalah cetakan putu. Cetakan putu ini terbuat dari bambu dengan diameter sekitar $3 \mathrm{~cm}$ dan tinggi sekitar $7 \mathrm{~cm}$. setelah penggunaan cetakan, cetakan langsung dicuci untuk membersihkan sisa adonan. Peralatan keempat adalah kukusan putu. Kukusan ini merupakan modifikasi karena berbentuk persegi dengan 20 lubang, seperti ditunjukkan pada Gambar 2.

Namun peralatan ini masih kurang memberikan hasil maksimum karena peralatan ini hanya memiliki lubang 20 sehingga ketika terdapat banyak pembelian, pelanggan menunggu dalam waktu yang lama. Peralatan kelima adalah sutil yang digunakan untuk memindahkan putu ayu dari cetakan ke tempat yang telah disediakan. Peralatan keenam adalah wadah yang digunakan untuk menyimpan 
topping dan adonan. Namun wadah topping tersebut masih belum terkoordinasi dengan baik. Hal ini dikarenakan gerobak yang digunakan tidak memiliki rak-rak untuk penyimpanan, seperti terlihat pada gambar 3 .

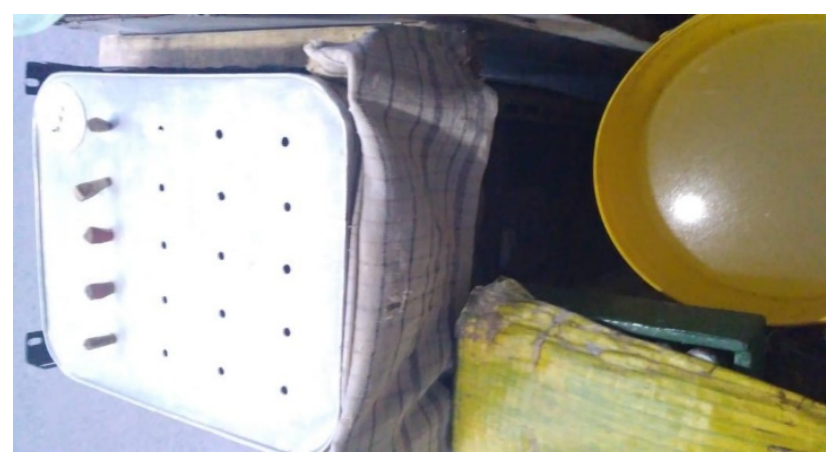

Gambar 2. Cetakan Putu

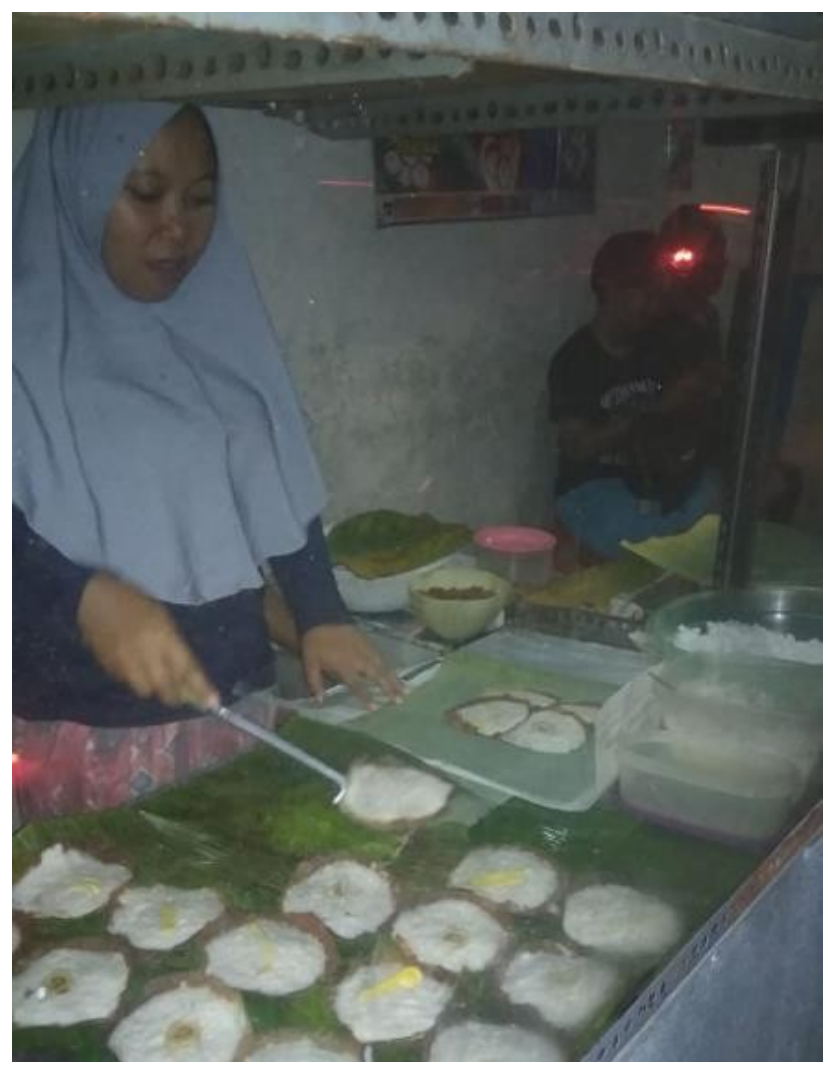

Gambar 3. Gerobak

UMKM melakukan inovasi produk dengan memberi variasi topping yang lebih beragam jika dibandingkan dengan awal berdirinya usaha ini. Kini Apem selong memiliki variasi topping, yaitu: pisang, nangka, coklat, dan keju. Sedangkan putu ayu memiliki variasi topping, yaitu: gula merah, gula putih, dan tawar. Harga jual yang ditawarkan pun cukup murah, putu ayu diberi harga Rp1.000,00. Harga jual apem selong dengan harga Rp1.500, kecuali apem selong dengan topping keju dihargai Rp2.000,00. Padahal jika dibandingkan d tempat lain, putu sudah diberi harga Rp5.000 untuk 3 buahnya, dan Rp2.000 untuk apem selongnya.

Kemasan produk yang dihasilkan adalah menggunakan daun yang dilapisi Koran, seperti Gambar 4. Penggunaan daun untuk menjaga ketradisionalan kue apem dan mempertahankan cita rasa aroma daun. Namun penggunaan koran kurang elok dan kurang higienis. Seharusnya penggunaan koran tersebut dapat diganti dengan penggunaan dus yang diberi logo usaha.

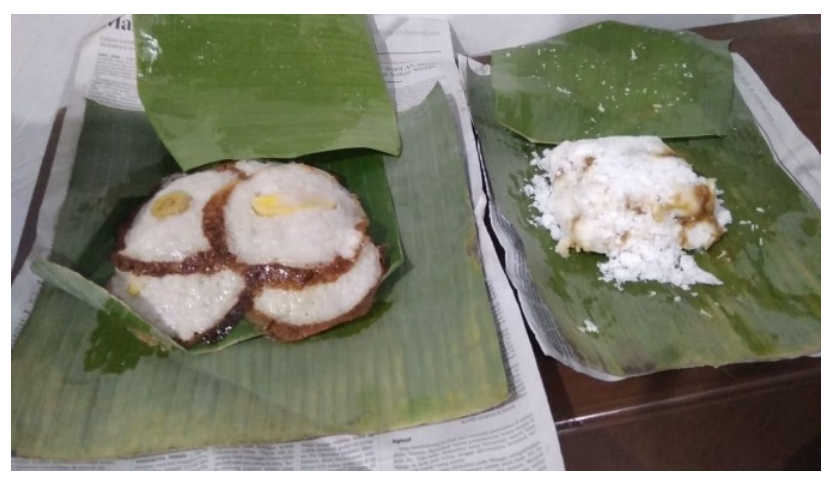

Gambar 4. Kemasan apem selong dan putu

Berdasarkan permasalahan mitra tersebut maka pada program pengabdian ini akan dilakukan penyelesaian mitra melalui peningkatan kualitas teknologi produksi dan tata kelola usaha. Kegiatan PKM ini dilakukan dengan tujuan untuk meningkatkan perkembangan dari usaha Apem Selong dan putu Dahlok Jember dari segi tempat usaha, peralatan, pemasaran, kebersihan dan produk. Dengan demikian, usaha Apem Selong dan Putu Dahlok ini bisa lebih optimal dalam memperoleh keuntungan.

\section{Metodologi}

Program pengabdian ini akan dilakukan pada usaha Apem Selong \& Putu Dahlok Jember. Usaha ini terletak di Jl. Fatahilah, Tembaan, Kepatihan, Kec. Kaliwates, Kabupaten Jember Provinsi Jawa Timur. Usaha Apem Selong \& Putu Dahlok Jember ini dijadikan sebagai mitra pengabdian karena usaha ini merupakan usaha kuliner yang sudah lama dan cukup dikenal di Kabupaten Jember. Usaha ini sudah dimulai secara turun-temurun selama 61 tahun yang lalu. 
Selain itu, usaha ini juga memiliki berbagai macam produk seperti apem rasa pisang, nangka coklat, putu rasa gula merah, gula putih, dan tawar. Dengan demikian, program pengabdian ini diharapkan mampu untuk turut berkontribusi untuk mengembangkan usaha yang legendaris ini menjadi usaha yang lebih baik lagi. Harapannya adalah agar makanan tradisional yang dijual oleh usaha ini terus bisa dinikmati oleh seluruh warga Jember dalam jangka waktu yang lama.

Pelaksanaan kegiatan pengabdian masyarakat ini dilakukan dengan beberapa metode yaitu survei lapangan, ceramah, renovasi, pelatihan, praktik, dan diskusi. Penjelasan secara lebih mendalam terkait sistematika metode kegiatan pengabdian ini adalah sebagai berikut:

\subsection{Survei Lapangan}

Metode yang pertama dilakukan adalah metode survei lapangan. Survei ini dilakukan dengan mengunjungi secara langsung lokasi tempat mitra melakukan bisnis. Tujuannya adalah untuk lebih mendalami bagaimana proses bisnis mitra untuk dapat menciptakan program yang sesuai dengan kondisi mitra.

\subsection{Ceramah}

Metode selanjutnya adalah metode ceramah. Metode ini dilakukan dengan tujuan untuk memberikan dan menumbuhkan motivasi bagi mitra untuk memiliki keinginan melakukan perbaikan usaha yang meliputi perhitungan harga jual yang tepat, perbaikan sarana dan prasarana, melakukan proses bisnis secara digital, dan melakukan inovasi pada produk yang sudah ada.

\subsection{Perbaikan Teknologi Produksi}

Metode ketiga yang dilakukan pada kegiatan ini adalah perbaikan teknologi produksi. Pada metode ini akan dilakukan penggantian peralatan mitra yang digunakan untuk membuat apem dan putu dari peralatan yang lama menjadi peralatan yang baru. Tujuan dari metode ini adalah agar proses pembuatan produk apem dan putu dari mitra dapat berjalan lebih cepat dan optimal.

\subsection{Perhitungan dan Pelatihan Biaya Produksi}

Metode yang terakhir dilakukan adalah melakukan perhitungan dan pelatihan biaya produksi. Tujuan dari dilakukannya metode ini adalah untuk menentukan secara tepat besaran biaya produksi yang dikeluarkan oleh mitra untuk menghasilkan produk apem dan putu yang dijualnya. Dengan demikian, penentuan laba mitra akan menjadi lebih tepat jika biaya produksi yang dikeluarkan dapat diketahui secara lebih pasti dan tepat

\section{Pembahasan}

Solusi yang pertama adalah perbaikan kualitas usaha mitra. Hal ini dikarenakan mitra memiliki masalah terkait tempat usaha dan peralatan yang dimiliki untuk menjalankan usaha. Perbaikan tempat usaha mitra dilakukan melalui merenovasi tempat usaha mitra. Hal ini ditujukan agar mitra dan konsumen lebih nyaman berada pada tempat tersebut, sehingga harapannya adalah untuk menarik konsumen. Oleh karena itu, PKM ini akan melakukan perbaikan teknologi produksi.

Perbaikan peralatan dilakukan dengan menambah atau memperbarui peralatan yang sebelumnya dimiliki oleh mitra. Dengan demikian, perbaikan peralatan perlu dilakukan agar usaha mitra lebih efisien dan efektivitas dalam menghasilkan produk, sehingga keuntungan yang diperoleh menjadi lebih optimal. Perbaikan peralatan ini akan sepenuhnya melibatkan mitra dalam hal penentuan spesifikasi alat yang akan digunakan. Hal ini dikarenakan mitra merupakan pihak yang mengetahui spesifikasi seperti apa yang harus ada dalam alat yang akan digunakan. Adapun alat yang dibutuhkan oleh usaha apem selong dan putu Dahlok adalah:

\subsubsection{Kompor dengan ukuran dan tekanan api yang lebih besar.}

Tujuannya agar proses pembuatan apem dan putu lebih cepat karena api yang kuat bisa menghasilkan uap yang lebih banyak. 


\subsubsection{Panci putu dengan ukuran yang lebih besar dan berbahan stainless steel.}

Panci ini sangat dibutuhkan oleh mitra agar proses pembuatan putu bisa lebih cepat, sehingga konsumen tidak perlu menunggu terlalu lama. Selain itu, panci untuk memasak putu yang dimiliki oleh mitra saat ini sudah rusak, sehingga perlu untuk diganti.
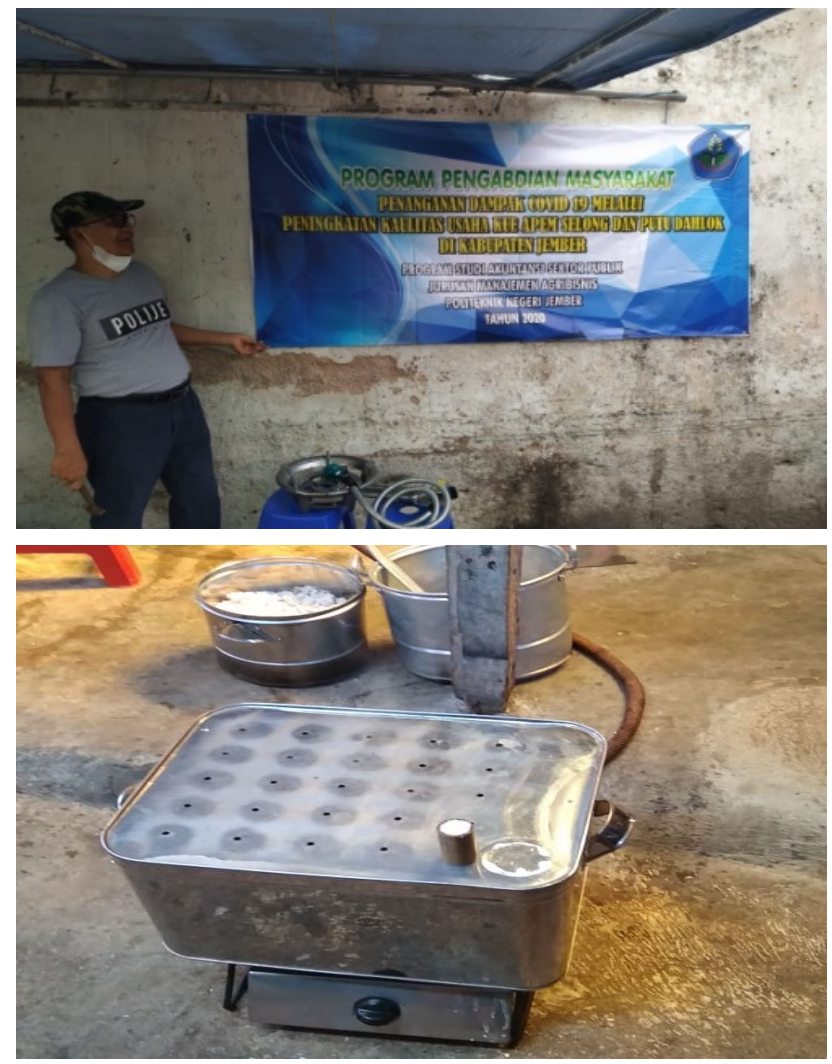

Gambar 5. Peningkatan Kualitas Teknologi Produksi

Kegiatan pengabdian kedua adalah pelatihan perhitungan harga jual. Usaha mitra yang sudah dilakukan sejak 64 tahun yang lalu ini sudah selayaknya untuk ditingkatkan kualitas penentuan harga jual atas produk yang dihasilkan. Hal ini dikarenakan agar harga jual yang dibebankan kepada konsumen tersebut tidak salah, sehingga menyebabkan untung yang diperoleh menjadi tidak optimal yang pada akhirnya membuat usaha menjadi tidak mengalami perkembangan secara signifikan. Sehingga PKM ini ingin melakukan pelatihan perhitungan harga jual untuk menentukan harga jual yang cocok untuk produk yang dijual.

Pelatihan perhitungan harga jual diharapkan dapat membuat mitra memahami bagaimana cara menghitung harga jual yang baik dan benar, sehingga untung yang diperoleh menjadi maksimal. Keahlian yang diperoleh dari hasil pelatihan ini nantinya juga dapat digunakan oleh mitra ketika menentukan harga jual untuk produk baru yang akan dikembangkan oleh mitra. Harga jual yang tepat akan menjadi suatu bentuk keunggulan kompetitif baru yang dimiliki oleh mitra. Hal ini dikarenakan mitra mampu menyediakan manfaat yang mendukung dengan harga jual yang ditawarkan kepada pelanggan [4].

Pelatihan perhitungan harga jual ini didasarkan pada ilmu akuntansi biaya terkait konsep harga pokok produksi baik yang massal atau pesanan. Adapun detail bentuk pelatihan perhitungan harga jual ini adalah sebagai berikut:

\subsubsection{Pengujian harga jual produk yang sudah ada.}

Kegiatan pelatihan yang pertama dilakukan adalah menguji harga jual produk yang sudah ada. Tujuannya adalah untuk mengetahui apakah harga jual produk yang sudah ada saat ini sudah mampu menghasilkan persentase keuntungan yang diinginkan atau belum dengan memasukkan seluruh unsur biaya sesuai dengan konsep akuntansi biaya. Berikut merupakan perhitungan harga pokok produksi dari produk apem selong dan putu Dahlok. 
Tabel 1. Harga Pokok Produksi Apem Selong dalam satu hari

\begin{tabular}{|c|c|c|c|c|c|c|}
\hline No & Nama Bahan & Kebutuhan & \multicolumn{2}{|c|}{ Harga Per unit } & \multicolumn{2}{|c|}{ Harga Total } \\
\hline \multicolumn{7}{|c|}{ Bahan Baku } \\
\hline 1. & Beras & $3,5 \mathrm{~kg}$ & $\mathrm{Rp}$ & $12.000,-$ & $\mathrm{Rp}$ & 42.000,- \\
\hline 2. & gula merah & $1 \mathrm{~kg}$ & $\mathrm{Rp}$ & $19.000,-$ & $\mathrm{Rp}$ & 19.000,- \\
\hline 3. & gula putih & $1,25 \mathrm{~kg}$ & $\mathrm{Rp}$ & $21.000,-$ & $\mathrm{Rp}$ & 26.250,- \\
\hline 4. & Kelapa & 5 buah & $\mathrm{Rp}$ & $9.000,-$ & $\mathrm{Rp}$ & $45.000,-$ \\
\hline 5. & Keju & 1 pack & $\mathrm{Rp}$ & $5.250,-$ & $\mathrm{Rp}$ & $5.250,-$ \\
\hline \multirow[t]{2}{*}{6.} & Meses & $125 \mathrm{gr}$ & $\mathrm{Rp}$ & $4.200,-$ & $\mathrm{Rp}$ & $5.250,-$ \\
\hline & Sub Total & & & & $\mathbf{R p}$ & 142.750,- \\
\hline \multicolumn{7}{|c|}{ Biaya Overhead } \\
\hline \multirow[t]{2}{*}{1} & Gas & & & & $\mathrm{Rp}$ & $6.000,-$ \\
\hline & Sub Total & & & & $\mathbf{R p}$ & $6.000,-$ \\
\hline \multicolumn{7}{|c|}{ Biaya Tenaga Kerja } \\
\hline 1. & Biaya Transport (becak) & & & & $\mathrm{Rp}$ & 17.500,- \\
\hline \multirow[t]{2}{*}{2.} & Biaya Tenaga Kerja & & & & $\mathrm{Rp}$ & $12.500,-$ \\
\hline & Sub Total & & & & $\mathbf{R p}$ & 30.000,- \\
\hline \multicolumn{7}{|c|}{ Biaya Kemasan } \\
\hline 1 & Koran & $0,5 \mathrm{~kg}$ & $\mathrm{Rp}$ & $10.000,-$ & $\mathrm{Rp}$ & $5.000,-$ \\
\hline 2 & Daun & & & & $\mathrm{Rp}$ & $12.500,-$ \\
\hline \multirow[t]{3}{*}{3} & Kresek & & & & $\mathrm{Rp}$ & $3.450,-$ \\
\hline & Sub Total & & & & $\mathbf{R p}$ & 20.950,- \\
\hline & TOTAL & & & & $\mathbf{R p}$ & 199.700,- \\
\hline
\end{tabular}


Tabel 2. Harga Pokok Produksi Putu Dahlok dalam satu hari

\begin{tabular}{|c|c|c|c|c|}
\hline No & Nama Bahan & Kebutuhan & Harga Per unit & Harga Total \\
\hline \multicolumn{5}{|c|}{ Bahan Baku } \\
\hline 1. & Beras & $1,5 \mathrm{~kg}$ & Rp 12.000,- & $\mathrm{Rp} \quad 18.000$, \\
\hline 2. & gula putih & $0,25 \mathrm{~kg}$ & Rp 21.000,- & $\mathrm{Rp} \quad 5.250,-$ \\
\hline 3. & Kelapa & 5 buah & Rp 9.000,- & $\mathrm{Rp} \quad 45.000$, \\
\hline 4. & tep beras & $1 \mathrm{~kg}$ & $\mathrm{Rp} \quad 6.500,-$ & $\mathrm{Rp} \quad 6.500,-$ \\
\hline 5. & Nangka & & Rp 15.000,- & $\mathrm{Rp} \quad 15.000,-$ \\
\hline 6. & pisang & & Rp 15.000,- & $\mathrm{Rp} \quad 15.000,-$ \\
\hline 7. & Keju & & $\mathrm{Rp} \quad 5.250,-$ & $\mathrm{Rp} \quad 5.250,-$ \\
\hline 8. & Meses & $125 \mathrm{gr}$ & $\mathrm{Rp} \quad 4.200,-$ & $\mathrm{Rp} \quad 5.250,-$ \\
\hline 9. & Vanili & 10 biji & $\mathrm{Rp} \quad 500,-$ & $\mathrm{Rp} \quad 5.000,-$ \\
\hline \multirow[t]{2}{*}{10.} & Telor & $0,25 \mathrm{~kg}$ & & $\mathrm{Rp} \quad 6.000,-$ \\
\hline & Sub Total & & & Rp 142.750,- \\
\hline \multicolumn{5}{|c|}{ Biaya Overhead } \\
\hline \multirow[t]{2}{*}{1} & Gas & & & $\mathrm{Rp} \quad 6.000,-$ \\
\hline & Sub Total & & & Rp 6.000,- \\
\hline \multicolumn{5}{|c|}{ Biaya Tenaga Kerja } \\
\hline 1. & Biaya Transport (becak) & & & $\mathrm{Rp} \quad 17.500,-$ \\
\hline \multirow[t]{2}{*}{2.} & Biaya Tenaga Kerja & & & $\mathrm{Rp} \quad 12.500$, \\
\hline & Sub Total & & & Rp 30.000,- \\
\hline \multicolumn{5}{|c|}{ Biaya Kemasan } \\
\hline 1 & Koran & $0,5 \mathrm{~kg}$ & $\mathrm{Rp} 10.000,-$ & $\mathrm{Rp} \quad 5.000,-$ \\
\hline 2 & Daun & & & $\mathrm{Rp} \quad 12.500,-$ \\
\hline \multirow[t]{3}{*}{3} & Kresek & & & $\mathrm{Rp} \quad 3.450,-$ \\
\hline & Sub Total & & & Rp 20.950,- \\
\hline & TOTAL & & & Rp 183.200,- \\
\hline
\end{tabular}

Tabel 3. Perhitungan Pendapatan dan Keuntungan

\begin{tabular}{|c|c|c|c|c|c|c|}
\hline No & Produk & Harga Jual & Jumlah Produk & Pendapatan Total & Biaya & Keuntungan \\
\hline 1 & Putu & Rp 1.000,- & 280 biji & Rp 280.000,- & & \\
\hline \multicolumn{4}{|c|}{ Sub Total } & Rp 280.000,- & Rp 183.200,- & Rp 96.800,-- \\
\hline \multirow[t]{2}{*}{2} & Apem & Rp 2.000,- & 120 biji & Rp 240.000,- & & \\
\hline & Apem keju & Rp 2.500,- & 20 biji & Rp 50.000,- & & \\
\hline \multicolumn{4}{|c|}{ Sub Total } & Rp 290.000,- & Rp 199.700,- & Rp 90.300,-- \\
\hline \multicolumn{4}{|c|}{ Total } & Rp 570.000,- & Rp 382.900,- & Rp 189.100,- \\
\hline
\end{tabular}


Berdasarkan perhitungan di atas, diketahui bahwa usaha Apem Selong dan Putu Dahlok mendapatkan keuntungan sebesar Rp189.100,per hari jika seluruh produknya terjual. Keuntungan ini diperoleh dari selisih pendapatan dengan biaya.

\subsubsection{Pemberian materi perhitungan harga pokok produksi.}

Kegiatan pelatihan yang kedua adalah melakukan pemberian materi terkait perhitungan harga pokok pesanan dan proses sesuai dengan konsep akuntansi biaya. Harapannya agar mitra bisa mengetahui bagaimana cara menentukan harga jual yang benar, sehingga bisa digunakan untuk keperluan usaha mitra, terutama untuk penentuan harga jual bagi produk baru yang ingin dikembangkan.

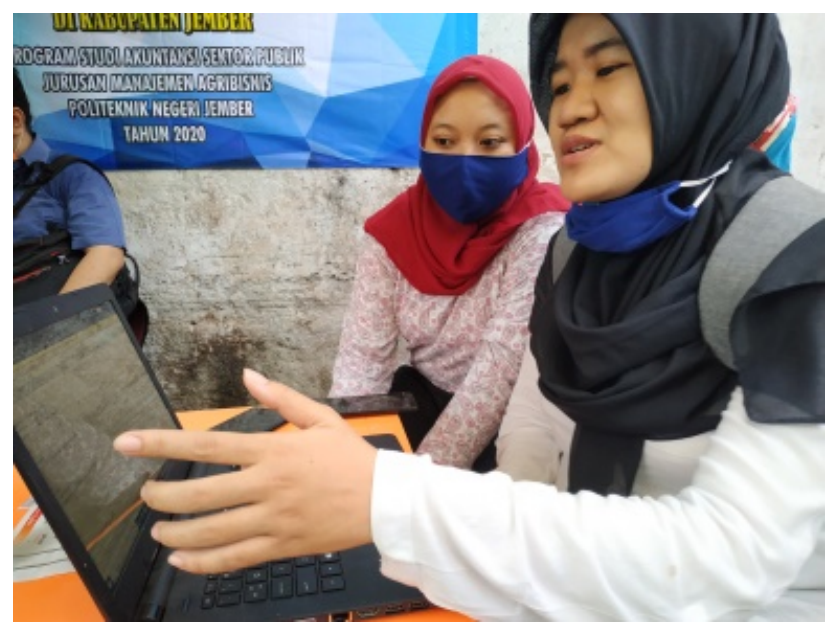

Gambar 6. Pelatihan penentuan harga Jual

\section{Kesimpulan}

Kegiatan Pengabdian kepada Masyarakat di Usaha Apem Selong dan Putu Dahlok telah dilaksanakan dengan baik. Mitra telah diberikan pelatihan terkait e-marketing, penghitungan harga jual dan inovasi produk. Serta telah diberikan sarana dan prasarana untuk menunjang kegiatan produksi, seperti kompor dan selang gas, panci putu, tempat cuci tangan, meja, kursi dan payung tenda. Hal ini diharapkan dapat meningkatkan pendapatan usaha tersebut, terutama di tengah pandemi seperti ini.

Pelaksanaan program pengabdian ini diharapkan dapat memberikan manfaat kepada mitra. Selain itu, terdapat beberapa saran yang dapat diberikan terkait pelaksanaan program pengabdian ini adalah sebagai berikut.

a. Mitra pengabdian yaitu usaha Apem Selong dan Putu Dahlok dapat menggunakan peralatan yang telah diberikan secara maksimal untuk meningkatkan kualitas usaha yang dijalankan.

b. Mitra pengabdian yaitu usaha Apem Selong dan Putu Dahlok dapat menerapkan ilmu yang telah diperoleh dari pelatihan penghitungan harga jual untuk menaikkan harga jual produk karena harga produk yang ditawarkan cukup terjangkau. Hal ini untuk meningkatkan laba dari usaha tersebut.

\section{Daftar Pustaka}

[1] www.covid19.go.id

[2] Kompas TV. 2020. Jalan Kota dan Pasar Tradisional di Tutup. https://www.kompas.tv/article/73947/jalan-kotadan-pasar-tradisional- ditutup-terbatas (diakses: 16 April 2020)

[3] Nurhidayat, L.T. P. 2020. Pengaruh Covid-19 Terhadap Pertumbuhan UMKM di Indonesia. https://sukabumiupdate.com/detail/balewarga/opini/67200- Pengaruh-Covid-19-TerhadapPertumbuhan-UMKM-di-Indonesia (diakses: 16 April 2020).

[4] Kotler, Philip., \& Gary Armstrong., 2005. Manajemen Pemasaran Analisis, Perencanaan Dan Pengendalian, Jilid Dua, Erlangga, Jakarta. 